\title{
CITRA PEMERINTAH TERKAIT PEMBERITAAN KASUS SUAP WALIKOTA TASIKMALAYA DI MEDIA ONLINE RADARTASIKMALAYA.COM
}

\author{
AdindaAlfira M.P, Suwandi Sumartias, Heru Rianto Budiana \\ Email: adinda16005.unpad.ac.id \\ Fakultas Ilmu Komunikasi \\ Universitas Padjadjaran, Kota Bandung, Indonesia \\ J1. Raya Bandung Sumedang KM.21, Hegarmanah, Jatinangor, \\ Kabupaten Sumedang, JawaBarat 45363. \\ Submitted: 19 Februari 2021 | Accepted: 24 Maret 2021 | Published: 30 Juni 2021 \\ Website: https://e-journal.umc.ac.id/index.php/jike/index
}

\begin{abstract}
Currently the development to information and technological advances are increasingly developing in humanlife. Moreover, thema as media that play a role in delivering the news, become one of the powerful channels in influencing and convincing the public in forming a public opinion. Such as the issue of the bribery of the Mayor of Tasikmalaya related to the gratuities of DID and DAK in 2019 which affected the wheels of governance in the City of Tasikmalaya, one of which is the image of the Tasikmalaya City government in the eye so fits people. The purpose of this study, researchers want to know the image of the Tasikmalaya City government from the framing of the bribery of DID and DAK funds carried out bythe Mayor of Tasikmalaya in 2019 in the online media radartasikmalaya.com. This research uses the constructivist paradigm with Robert $N$. Entman's framing analysis study model as a conceptual foundation with Entman'sframing conception, which is defining the problem, estimating the cause, making moral decisions, and emphasizing the solution in terms of the news writer or reporter. The results of framing research conducted by online media radartasikmalaya.com on the government's image related to the bribery case of Mayor of Tasikmalaya tend to be in a neutral context, because the news contained has a balanced content by including the opinions of various parties involved in it. Although the news is included in the bad news model, but the image of the Tasikmalaya City government has not become worse with the news, this is because the government did not counter the news, instead it was offset by positive reporting regarding the development of the City of Tasikmalaya.
\end{abstract}

KeyWords : online media, image, framing bribery case of Mayor Tasikmalaya, radartasikmalaya.com

\begin{abstract}
ABSTRAK
Saat ini perkembangan informasi serta kemajuan teknologi semakin berkembang di kehidupan manusia. Terlebih media massa yang berperan dalam menyampaikan berita, menjadi salah satu saluran yang ampuh dalam mempengaruhi dan menyakinkan masyarakat dalam membentuk suatu opini publik. Seperti persoalan kasus suap Walikota Tasikmalaya terkait gratifikasi DID dan DAK tahun 2019 yang berpengaruh terhadap roda pemerintahan Kota Tasikmalaya, salah satunya yakni citra pemerintah Kota Tasikmalaya di mata masyarakatnya.

Tujuan dari penelitian ini, peneliti ingin mengetahui citra pemerintah Kota Tasikmalaya dari pembingkaian pemberitaan kasus suap dana DID dan DAK yang dilakukan oleh Walikota Tasikmalaya pada tahun 2019 di media online radartasikmalaya.com. penelitian ini menggunakan paradigm konstruktivisme dengan studi analisis framing model Robert N. Entman sebagai landasan konseptual dengan konsepsi framing Entman yaitu pendefinisian masalah, memperkirakan penyebab, membuat keputusan moral, dan menekankan penyelesaian dari sisi penulis berita atau wartawan. Hasil penelitian framing yang dilakukan oleh media online radartasikmalaya.com terhadap citra pemerintah terkait kasus suapWalikotaTasikmalaya cenderung masih dalam konteks netral, karena pemberitaan yang dimuat memiliki isi yang berimbang dengan memasukan opini dari berbagai pihak yang terlibat didalamnya. Walaupun pemberitaan tersebut masuk ke dalam model bad news, tetapi citra pemerintah Kota Tasikmalaya tidak menjadi buruk dengan adanya pemberitaan tersebut, hal ini karena pemerintah tidak meng-counter pemberitaan tersebut, justru diimbangi oleh pemberitaan positif berkaitan pembangunan Kota Tasikmalaya.
\end{abstract}

Kata Kunci : media online, citra, framing, suap walikota, radartasikmalaya.com

\section{A. PENDAHULUAN}


Praktik suap-menyuap di Indonesia bukanlah menjadi sebuah hal yang baru. Dikatakan demikian, karena peristiwa tersebut telah terjadi sejak dahulu sehingga sudah dianggap menjadi hal yang biasa untuk dilakukan, walaupun ada hukum yang telah mengaturnya. Praktik suap menyuap ini sudah sering kali ditemukan di dalam institusi pelayanan yang berkaitan dengan publik.

Penyuapan sendiri diartikan sebagai tindakan menawarkan, memberikan, menerima, atau juga meminta nilai dari suatu barang untuk mempengaruhi tindakan pegawai ataupun Lembaga yang bertanggungjawab atas kebijakan umum atau peraturan hukum. Sehingga dapat diartikan jika penyuapan adalah tindakan memberikan atau meminta uang, barang, atau bentuk lain dari pemberi suap kepada pihak yang menerima suap dengan maksud agar penerima suap ini memberikan kemudahan berupa tindakan atau kebijakan dalam wewenang penerima suap sesuai dengan kepentingan dari pemberi suap.

Lebih lanjut lagi dikatakan jika suap dapat membuat orang yang berhak kehilangan haknya, dan orang-orang yang tidak berhak mendapatkannya. Suap adalah sesuatu yang sangat merusak tatanan masyarakat. Apabila jika suap telah menjadi kebiasaan atau tradisi, maka bisa menghancurkan sebuah negara. Yang menjadi korbannya ialah rakyat dan juga generasi penerus bangsa dengan kondisi negara yang carut-marut. Suap seperti penyakit yang secara diam-diam menggerus keadilan dan kemanusiaan.

Dengan maraknya kasus tindakan suap menyuap yang dilakukan oleh penjabat pemerintah dalam struktur kehidupan sosial manusia di sepanjang periode waktu, tentu mengundang ketertarikan media massa dalam menjadikan kasus tindakan suap tersebut sebagai headlinedi setiap berita yang dikeluarkan, baik itu media cetak maupun elektronik, hal ini karena sudah dianggap memberikan dampak negatif bagi kehidupan manusia. Munculnya pemberitaan ini semakin menguatkan jika kasus suap menyuap serta masalah korupsi merupakan bagian dari patologi sosial masyarakat Indonesia yang harus diperangi dengan lebih serius lagi, tak lupa dengan tetap mengedepankan instrument hukum, agama, maupun sosial budaya.

Tanpa disadari dampak yang terlihat dari munculnya kasus ini adalah berkaitan dengan citra pihak atau pun institusi yang terlibat didalam masalah ini. Citra merupakan asset penting yang harus senantiasa dipelihara dan juga dijaga. Citra sendiri memiliki arti abstrak ataupun intangible, akan tetapi wujudnya bisa dirasakan hasil dari penilaian, penerimaan, kesadaran dan pengertian, baik itu semacam tanda respek dan hormat, dari publik sekelilingnya atau masyarakat luas terhadap perusahaan atau institusi sebagai sebuah badan 
usaha ataupun personelnya.Tentunyacitra dari sebuah pemerintahan merupakan hal yang penting dan riskan, dapat dikatakan jika citra akan menjadi kunci apakah suatu organisasi atau pemerintah dapat mudah diterima di dalam masyarakat atau justru sebaliknya.

Tak ayal munculnya kasus suap menyuap yang melibatkan aparatur negara, selalu menjadi pemberitaan yang kerap dijadikan pembahasan, terlebih kecepatan serta kecanggihan teknologi komunikasi yang dengan mudah memperluas jaringan pemberitaan hingga ke pelosok daerah semakin mempermudah penerimaan berita atau pun informasi untuk masyarakat.

\section{B. KAJIAN LITERARUR}

Dewasa ini teknologi komunikasi semakin berkembang dari hari ke hari. Salah satu yang berkembang sangat pesat yakni dengan hadirnya new media seperti situs berita online. Hal ini tidak terlepas dari kebutuhan masyarakat akan informasi sebagai bagian dari gaya hidup. Situs berita onlinesendiri memiliki karakteristik seperti media massa yang saat ini ada yakni sama-sama menyajikan informasi dan berita yang aktual. Informasi yang diangkat pun beragam seperti, sosial, budaya, ekonomi, politik, gender dan masih banyak lainnya yang menyangkut aspek dari kehidupan manusia.

Sebagai sebuah media yang terbilang cukup baru, situs berita online memiliki cara tersendiri dalam menyajikan berita. Hal ini juga berkaitan dengan netralitas dan juga obyektifitas media saat melaporkan peristiwa. setiap media maupun wartawan selalu memiliki latar belakang dan berbagai faktor lainnya yang mempengaruhi cara berpikir, bertindak, dan memilih informasi untuk ditulis.

Althauser dan Gramsci (Sobur 2006:30) berpendapat bahwa media massa bukanlah sesuatu yang bebas dan independent tetapi erat kaitannya dengan realitas sosial, ada berbagai kepentingan dalam setiap media, seperti kepentingan kapitalisme pemilik modal, kepentingan ekonomi dan lainnya. Dengan adanya kepentingan di dalam institusi media massa menyebabkan institusi media menjadi tidak netral.

Setiap media memiliki gaya masing-masing dalam penulisan beritanya, mengingat bahwa media bukanlah saluran yang bebas tetapi telah mengkonstruksi berita sedemikian rupa. Sebuah peristiwa yang sama dapat diperlakukan secara berbeda oleh media. Ada peristiwa yang diberitakan, dan ada yang tidak diberitakan, ada aspek yang ditonjolkan, dan ada aspek yang dihilangkan. Semua ini mengarah pada salah satu konsep yang disebut sebagai framing. Framing adalah salah satu cara bagaimana peristiwa disajikan media dengan 
menekankan pada beberapa bagian tertentu, menonjolkan aspek tertentu, dan membesarkan cara berita tertentu dari suatu realitas atau peristiwa sehingga dapat lebih mudah diingat oleh khalayak (Eriyanto, 2002:77). Pada dasarnya framing adalah metode untuk melihat cara bercerita (storytelling) media atas peristiwa. Cara bercerita itu tergambar pada "cara melihat" terhadap realitas yang dijadikan berita. "Cara melihat" ini berpengaruh pada hasil akhir dari konstruksi realitas.

\section{B. METODE PENELITIAN}

Penelitian ini menggunakan metode deskriptif dengan sifat data kualitatif. Menurut Nazir (2005:54), metode deskriptif adalah suatu metode dalam meneliti status kelompok manusia, suatu objek, suatu set kondisi, suatu sistem pemikiran, ataupun suatu kelas peristiwa pada masa sekarang. Metode deskriptif dilakukan untuk membuat gambaran mengenai suatu situasi atau kejadian, dilakukan secara sistematis dalam menyampaikan suatu fakta atau fenomena.

Penelitian deskriptif tidak menjelaskan hubungan, dan tidak menguji hipotesis atau membuat prediksi. Penelitian deskriptif lahir karena kebutuhan. Pejabat hubungan masyarakat ingin mengetahui citra Lembaga dalam persepsi publiknya. Penelitian deskriptif membuat peneliti terjun ke lapangan tanda dibebani ataupun diarahkan oleh sebuah teori. Peneliti tidak bermaksud untuk menguji teori sehingga perspektifnya tidak tersaring. Ia bebas untuk mengamati objeknya, menjelajah, dan menemukan wawasan sepanjang jalan. Penelitiannya terus-menerus mengalami reformulasi dan redireksi ketika informasi ditemukan. Hipotesis tidak datang sebelum penelitian, tetapi muncul dalam penelitian.

Tujuan dari penelitian ini adalah untuk mengetahui framing (pembingkaian) yang dilakukan radartasikmalaya.com terkait kasus suap Walikota Tasikmalaya dengan citra pemerintah. Teknik pengumpulan data yang dilakukan dengan pengambilan berita terkait kasus suap Walikota Tasikmalaya di radartasikmalaya.com lalu melakukan studi dokumentasi berupa dokumen-dokumen yang berkaitan dengan analisis framing model Robert N. Entman dan melakukan wawancara dengan pihak-pihak yang terlibat dalam pembuatan berita kasus suapWalikotaTasikmalaya di radartasikmalaya.com

Teknik analisis data yang digunakan yaitu menggunakan metode analisis framing menggunakan model Robert N Entman dengan paradigm konstruksionis. Model framing oleh Entman ini digunakan untuk menggambarkan proses seleksi isu dan menonjolkan aspek tertentu dari realitas oleh media massa. Peneliti memilih model framing Entman dalam 
penelitian ini dengan alasan bahwa perangkat frame Entman mampu membantu peneliti dalam mencaritahu framing pemberitaan kasus suap Walikota Tasikmalaya oleh radartasikmalaya.com.

Selain itu penelitian ini menggunakan pendekatan model paradigm konstruktivisme, Paradigma ini memandang realitas kehidupan sosial bukanlah realitas yang natural, tetapi hasil dari konstruksi. Karenanya, konsentrasi analisis dalam paradigma konstruktivisme adalah menemukan bagaimana peristiwa atau realitas tersebut dikonstruksi, dengan cara apa konstruksi itu dibentuk. Dalam studi komunikasi, paradigma konstruktivisme ini sering kali disebut sebagai paradigma produksi dan pertukaran makna.

Yang menjadi titik perhatian dari paradigm ini adalah bukan bagaimana seseorang mengirimkan pesan, tetapi bagaimana masing-masing pihak dalam lalu lintas komunikasi saling memproduksi dan mempertukarkan makna. Di sini diandaikan tidak ada pesan dalam arti yang statis yang saling dipertukarkan dan disebarkan. Pesan itu sendiri dibentuk secara bersama-sama antara pengirim dan penerima atau pihak yang saling berkomunikasi dan dihubungkan dengan konteks sosial di mana mereka berada. Fokus dari pendekatan ini adalah bagaimana pesan politik dibuat atau diciptakan oleh komunikator dan bagaimana pesan itu secara aktif ditafsirkan oleh individu sebagai penerima.

Dalam penelitian kualitatif, paradigma konstruktivisme digunakan untuk memahami dan menginterpretasikan suatu fenomena sosial yang terjadi di masyarakat. Paradigma ini menyatakan bahwa realitas itu ada dalam beragam bentuk konstruksi mental yang didasarkan pada pengalaman sosial. Dan berita adalah salah satu bentuk hasil dari konstruksi sosial yang selalu melibatkan pandangan, ideologi dan nilai-nilai dari wartawan atau media. Bagaimana realitas tersebut dijadikan berita sangat tergantung pada bagaimana fakta itu dipahami dan dimaknai (Eriyanto,2012:29). Dan analisis framing termasuk ke dalam paradigma konstruktivisme, dan paradigma ini memiliki posisi dan pandangan tersendiri terhadap media dan teks berita yang dihasilkannya.

Berdasarkan hasil yang telah dijabarkan diatas, bentuk dari framing yang dilakukan oleh media massa salah satunya dituangkan ke dalam teks, sekaligus merupakan hasil produksi dari sebuah keredaksian. Hal ini pula yang mendasari peneliti ingin meneliti isi pemberitaan mengenai Pemberitaan Kasus Suap Walikota Tasikmalaya di radartasikmalaya.com. Media ataupun pihak yang membuat berita dapat membingkai peristiwa dengan cara tertentu sesuai dengan bagaimana suatu peristiwa tersebut dipahami dan dimaknai oleh pembuat berita. 


\section{HASIL DAN PEMBAHASAN}

Analisis yang digunakan ini menggunakan model framing Robert N. Entman. Entman melihat framing dalam dua dimensi besarya itu seleksi isu dan penekanan atau penonjolan aspek-aspek tertentu dari realitas isu. Ketika aspek tertentu dari suatu peristiwa dipilih, bagaimana aspek tersebut ditulis.

Hal ini sangat berkaitan dengan pemakaian kata, kalimat, gambar dan citra tertentu untuk ditampilkan kepada khalayak. Misalnya penempatan-penempatan yang mencolok (di headline depan atau belakang), pengulangan, pemakaian grafis, pemakaian label tertentu untuk menggambarkan orang atau peristiwa, asosiasi terhadap simbol budaya, generalisasi, simplifikasi dan sebagainya.

Tabel 1 Model Analisis Framing Robert N. Entman

\begin{tabular}{|l|l|}
\hline Seleksi Isu & $\begin{array}{l}\text { Aspek ini berhubungan dengan pemilihan fakta. Dari realitas yang } \\
\text { kompleks dan beragam itu, aspek mana yang diseleksi untuk } \\
\text { ditampilkan? Dari proses ini selalu terkandung di dalamnya ada } \\
\text { bagian berita yang dimasukkan (included), tetapi ada juga berita } \\
\text { yang dikeluarkan (excluded). Tidak semua aspek atau bagian dari } \\
\text { isu ditampilkan, wartawan memilih aspek tertentu dari suatu dari } \\
\text { suatu isu. }\end{array}$ \\
\hline $\begin{array}{l}\text { Penonjolan aspek- } \\
\text { aspek tertentu dari isu }\end{array}$ & $\begin{array}{l}\text { Aspek ini berhubungan dengan penulisan fakta. Ketika aspek } \\
\text { tertentu dari suatu peristiwa/isu tersebut dipilih, bagaimana aspek } \\
\text { tersebut ditulis? Hal ini sangat berkaitan dengan pemakaian kata, } \\
\text { kalimat, gambar dan citra tertentu untuk ditampilkan kepada } \\
\text { khalayak. }\end{array}$ \\
\hline
\end{tabular}

Sumber : Buku Analisis Framing (Konstruksi, Ideologi dan Politik Media), 2005

Dari pemikiran diatas, Entman merumuskannya kedalam bentuk model framing sebagai berikut, yaitu :

Tabel 2: Konsep Analisis Framing Model Robert N. Entman

\begin{tabular}{|l|l|}
\hline $\begin{array}{l}\text { Define problems } \\
\text { ( pendefinisian masalah) }\end{array}$ & $\begin{array}{l}\text { Bagaimana suatu peristiwa atau isu dilihat? Sebagai apa? } \\
\text { Atau sebagai masalah apa? }\end{array}$ \\
\hline $\begin{array}{l}\text { Diagnose causes } \\
\text { (memperkirakan masalah atau } \\
\text { sumber masalah) }\end{array}$ & $\begin{array}{l}\text { Peristiwa itu dilihat disebabkan oleh apa? Apa yang } \\
\text { dianggap sebagai penyebab dari suatu masalah? Siapa } \\
\text { actor yang dianggap sebagai penyebab masalah }\end{array}$ \\
\hline $\begin{array}{l}\text { Make moral judgment } \\
\text { (membuatkeputusan moral) }\end{array}$ & $\begin{array}{l}\text { Nilai moral apa yang akan disajiakan untuk menjelaskan } \\
\text { masalah? Nilai moral apa yang dipakai untuk } \\
\text { melegitimasi atau mendealektika suatu tindakan }\end{array}$ \\
\hline
\end{tabular}


Treatment Recommendation

(Menakankanpenyelesaian)

Penyelesaian apa yang ditawarkan untuk mengatasi masalah? Jalan apa yang harus di tempuh untuk mengatasi masalah?

Sumber : Buku Analisis Framing (Konstruksi, Ideologi dan Politik Media), 2005

Berdasarkan framing di atas peneliti akan menganalisis pemberitaan sesuai dengan empat dimensi tersebut, kemudian hasil dari analisis tersebut nantinya akan diinterpretasikan sehingga dapat diketahui bagaimana radartasikmalaya.com membingkai berita terkait kasus suap Walikota Tasikmalaya terkait citra pemerintah Kota Tasikmalaya dengan menggunakan analisis model Robet N. Entman.

\section{Judul Pemberitaan pertama : "BelasanAnggota KPK Geledah Kantor Walikota Tasikmalaya, Kapolresta Lakukan Pengamanan"}

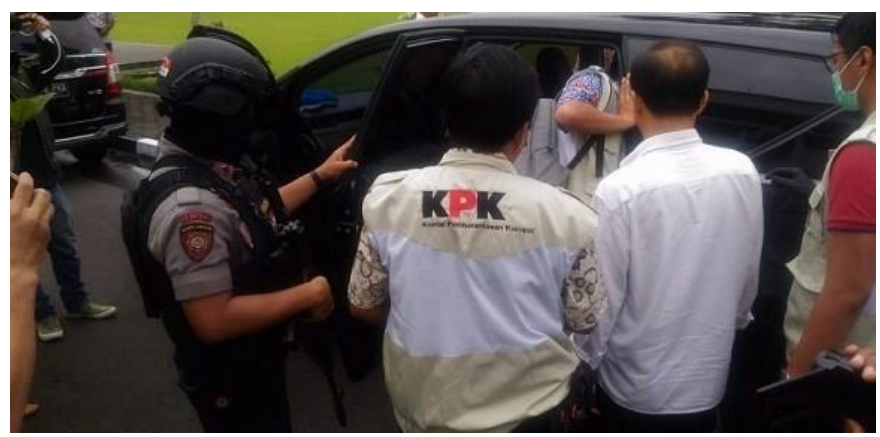

Sumber: radartasikmalaya.com, 2019

\section{Gambar 1. Sejumlah Anggota KPK Sedang Melakukan Penggeledahan di Kantor Walikota Tasikmalaya, Kapolres Melakukan Pengamanan}

Define Problems : Hal yang terlihat dalam pemberitaan dengan judul tersebut yakni berkaitan dengan fenomena kegaduhan akibat adanya penggeledahan yang dilakukan oleh KPK di Kantor Walikota Tasikmalaya pada 24 April 2019.

Isu akan kedatangan sejumlah anggota KPK ke kantor Walikota Tasikmalaya ini mengundang para pencari berita, bahkan beberapa media nasional pun turun langsung untuk meliput kegiatan ini.

Berbagai media yang pada saat itu berusaha untuk mendapatkan informasi mengenai kedatangan KPK ke kantor Walikota Tasikmalaya menimbulkan kegaduhan, terlebih sejumlah pejabat daerah yang terlihat hilir mudik di dalam kantor Walikota Tasikmalaya tersebut. Sejumlah media yang hadir pada saat itu hanya dapat melakukan peliputan dari lobby lantai satu kantor Walikota Tasikmalaya. 
Diagnose Cause : radartasikmalaya.com memperkirakan penyebab penggeledahan kantor Walikota Tasikmalaya akibat ditemukannya proposal usulan DID dan DAK Kota Tasikmalaya kepada Yaya Purnomo.

Dalam berita ini wartawan radartasikmalaya.com menjelaskan bahwa penyebab masalah ini mengenai penemuan proposal kasus suap anggaran DID dan DAK yang dilakukan oleh Walikota Tasikmalaya terhadap Yaya Purnomo.

Walaupun dari pemberitaan yang ada, pihak Polres Tasikmalaya tidak menjelaskan secara gamblang penyebab adanya kegiatan penggeledahan yang dilakukan oleh KPK serta adanya pengaman ketat oleh sejumlah aparat kepolisian, namun wartawan radartasikmalaya.com yang pada saat itu meliput kejadian memperkirakan masalah tersebut berkaitan dengan kasus suap anggaran DID dan juga DAK yang dilakukan oleh Walikota Tasikmalaya.

"Di pemberitaan sendiri tidak ada pernyataan langsung dari KPK maupun pihak kepolisian terkait penyebab dilakukannya penggeledahan, tapi dari kabar yang beredar terkait kasus suap anggaran DID sama DAK"menurut salah satu wartawan radartasikmalaya.com

Make Moral Judgement : Dalam hal ini Kapolresta Tasikmalaya selaku pihak yang ikut mengamankan jalannya penggeledahan membenarkan bahwa pihaknya dimintai bantuan untuk ikut mengamankan jalannya penggeledahan oleh KPK di Kantor Walikota Tasikmalaya.

“Belum tau terkait apa, kami hanya melakukan pengamanan saja.” (24/4/19)

Dalam hal ini wartawan belum melihat dan menemukan pembenaran dari pihak terkait atas penyebab terjadinya penggeledahan tersebut, wartawan berusaha menginterpretasi dari apa yang mereka lihat ditempat saja. Wartawan hanya melihat kesaksian maupun pernyataan langsung dari pihak kepolisian yang pada saat kejadian ikut melakukan pengamanan di Kantor Walikota Tasikmalaya

Treatment Recommendation : sayangnya dalam pemberitaan kali ini wartawan radartasikmalaya.com tidak memasukan Treatment Recommendation pada pemberitaan ini. 


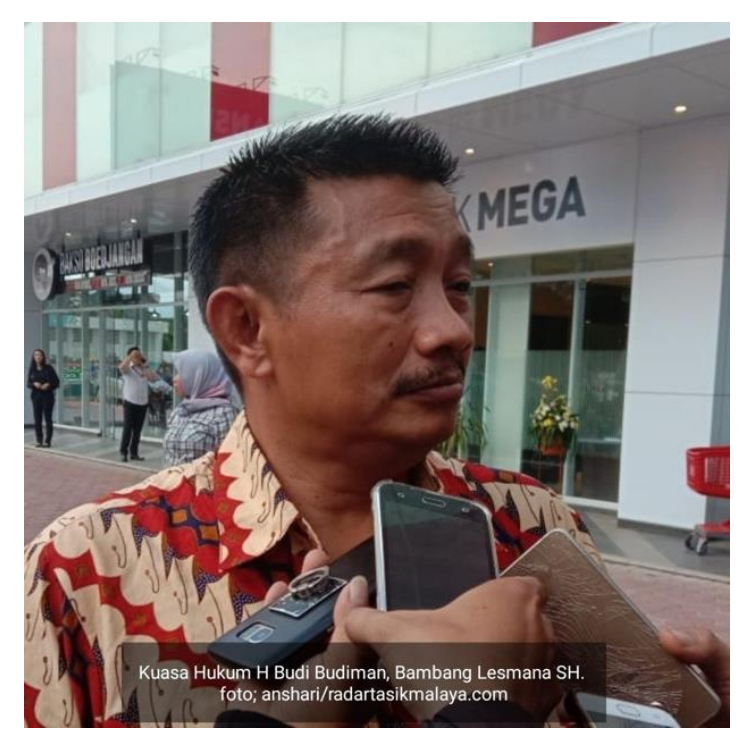

Sumber : radartasikmalaya.com, 2019

\section{Gambar 2. Kuasa Hukum Walikota Tasikmalaya Menyampaikan Klarifikasi Status Tersangka Walikota Tasikmalaya}

Define Problems : Ditengah status tersangka yang disematkan kepada Walikota Tasikmalaya, Budi Budiman masih tetap menjalankan tugas dan kewajibannya sebagai Walikota Tasikmalya.

"Hari ini (26/04/20) beliau (Budi Budiman) masih bekerja, dan statusnya masih sebagai Wali Kota”,

"Belum ada keputusan beliau diberhentikan maupun dis-korsing sebagai Walikota. Keputusan kita serahkan kepada pemerintah pusat."

Hal tersebut disampaikan oleh Wakil Walikota Tasikmalaya, H. M. Yusuf kepada radartasikmalaya.com saat diwawancarai terkait status tersangka Walikota Tasikmalaya.

Selain itu, dari fakta inilah yang jadi pertimbangan wartawan dalam mendefinisikan masalah jika Walikota Tasikmalaya masih menjalankan tugasnya ditengah statusnya yang kini menjadi tersangka oleh KPK.

Diagnose Cause : Dengan diterimanya surat dari KPK terkait status tersangka Walikota Tasikmalaya, pihak kuasa hokum Walikota Tasikmalaya membenarkan jika adanya keterlibatan Walikota Tasikmalaya atas proposal DID dan DAK kepada Yaya Purnomo.

"Yang menjadi permasalahan adalah terkait gratifikasi, dan perlu diluruskan “ (26/04/2020) ujar Bambang Lesmana S.H selaku kuasa hokum Walikota Tasikmalaya. 
Penekanan yang dilakukan oleh wartawan radartasikmalaya.com dalam memperkirakan masalah adalah mengenai status tersangka yang sudah diterima oleh Walikota Tasikmalaya. Tak ketinggalan, dalam pemberitaan tersebut, wartawan memberikan ringkasan terkait awal mula kasus ini muncul, serta keterlibatan Walikota Tasikmalaya di dalamnya.

Make Moral Judgement : Ditemuinya kuasa hokum WalikotaTasikmalaya, Bambang Lesmana S.H. Memperjelaskan bahwa kini status Walikota Tasikmalaya telah resmi sebagai tersangka dan masih menjalankan tugasya.

Di pemberitaan ini penonjolan terkait status Walikota Tasikmalaya sebagai tersangka disampaikan langsung oleh kuasa hukum Walikota Tasikmalaya, pernyataan tersebut merupakan hal wartawan angkat dalam pemberitaan ini.

"Pernyataan dari kuasa hukum beliau adalah bukti bahwa ia memang mengikuti proses hukum yang harus dilaluinya." Menurut salah satu wartawan radartasikmalaya.com.

Treatment Recommendation : Pihaknya mengatakan jika Walikota Tasikmalaya akan terus mengikuti seluruh proses hukum yang berjalan terkait kasus yang menimpanya. Selain itu, Walikota juga mengatakan hingga sampai saat ini pihaknya masih menjalankan tugas dan tanggungjawabnya sebagai Walikota Tasikmalaya, hal ini dikarenakan belum adanya keputusan pemberhentian maupun diskorsing dari pemerintah.

Didalam pemberitaan ini wartawan tidak lupa untuk ikut menuliskan penekanan masalah yang dikehendakinya, dalam hal ini ia menekankan penyesalan melalui pernyataan dari Walikota Tasikmalaya yang mengatakan bahkan ia akan menghargai dan mengikuti proses hukum yang ada.

Tak hanya itu saja, pernyataan dari Wakil Walikota Tasikmalaya terkait Walikota Tasikmalaya yang saat ini belum menerima surat penahanan ataupun diskorsing serta seluruh keputusan diserahkan langsung kepada pemerintah pusat adalah hal yang dijadikan wartawan sebagai penekanan masalah dalam pemberitaan ini.

\section{Judul Pemberitaan Ketiga : "Walikota Tasik Minta Maaf"}




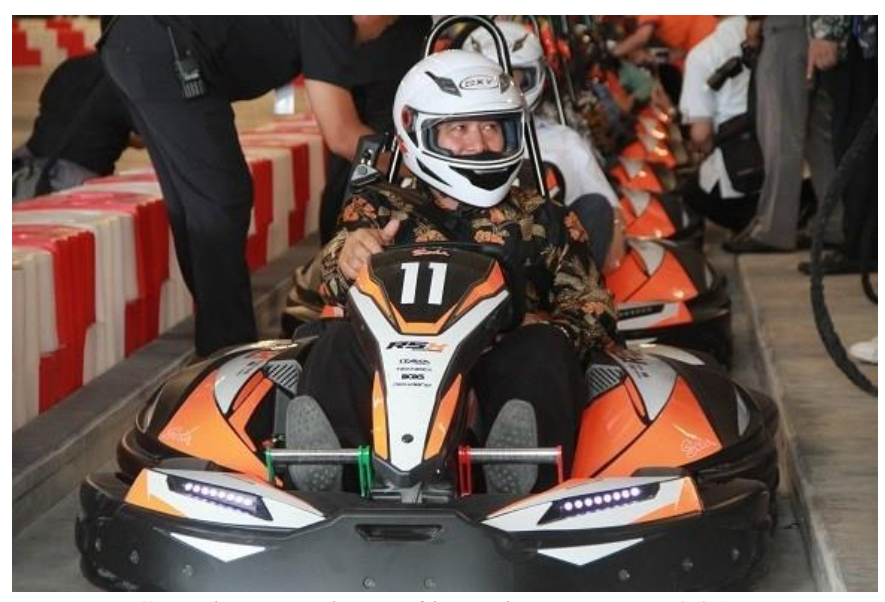

Sumber: radartasikmalaya.com, 2019

\section{Gambar 3. WalikotaTasikmalaya Sedang Menghadiri Pembukaan Transmart Tasikmalaya, Sekaligus Menyampaikan Permintaan Maaf}

Define Problems : Pada kesempatan pembukaan Transmart di Tasikmalaya, WalikotaTasikmalaya secara resmi menyampaikan permintaan maafnya terkait kasus yang menyeretnya. Ia menyampaikan permintaan maaf ini dihadapan seluruh masyarakat Kota Tasikmalaya yang hadir pada acara pembukaan Transmart pada (27/4/19).

"Kepada masyarakat Kota Tasik, saya meminta maaf, semuanya mungkin sudah mengetahui kami sedang menghadapi masalah. Mohon doanya semoga diberi kekuatan, kesabaran,"

Pada pemberitaan ini menjelaskan keberanian seorang publicfigure atau pemimpin daerah dalam menyampaikan permintaan maafnya dihadapan khalayak banyak. Ironi memang, ditengah tugasnya meresmikan salah satu pusat perbelanjaan di Kota Tasikmalaya dan juga bertepatan di hari ulang tahunnya, telah diterimanya surat keputusan tersangka oleh KPK menjadi sebuah hadiah pahit yang harus diterima Walikota Tasikmalaya, namun hal tersebut ia jadikan momentum untuk menyampaikan permintaan maaf kepada masyarakat yang hadir

Diagnose Cause : Pernyataan permintaan maaf yang dilakukan oleh Walikota Tasik ini tentunya berawal dari kasus suap gratifikasi DID dan DAK yang dilakukan oleh Walikota Tasikmalaya kepada Yaya Purnomo pada tahun 2018.

Keterlibatannya dalam kasus ini menumbuhkan rasa penyesalan dihati Walikota Tasikmalaya, dalam kegiatan pemberian sambutan pembukaan Transmart di Tasikmalaya ia menyampaikan permintaannya secara langsung dihadapan masyarakat kota.

Make Moral Judgement : Walikota Tasikmalaya secara langsung menyampaikan permintaan maaf dihadapan masyarakat Kota Tasikmalaya, tak lupa beliau juga 
menyampaikan berbagai percapaian yang telah Kota Tasikmalaya raih selama ia menjabat sebagai Walikota Tasikmalaya.

Dalam permintaan maaf yang disampaikan oleh Walikota ia menyampaikan rasa penyesalan dan meminta doa serta kekuatan untuk menghadapi masalah yang dihadapinya, karena sejatinya manusia tidak lepas dari kekurangan dan kesalahan.

Treatment Recommendation : dalam pemberitaan kali ini radartasikmalaya.com menampilkan jika Walikota Tasikmalaya telah menyiapkan tim kuasa hokum untuk membantunya dalam menyelesaikan kasus suap yang menjeratnya.

Sebagai seorang pemimpin daerah, yang mana pada saat ini terjerat kasus hukum, terlebih kasus yang menjeratnya ikut melibatkan kepentingan pemerintah didalamnya, maka tak menutup kemungkinan hal ini berdampak terhadap roda pemerintah yang saat ini ia pimpin. Tentunya dalam hal ini dibutuhkan tindakan-tindakan guna mencari jalan keluar dari setiap permasalahan yang muncul.

Tindakan yang dilakukan Walikota Tasikmalaya serta pemerintah Kota Tasikmalaya dalam memilih tim kuasa hukum untuk ikut mendampingi dalam menjalani kasus ini merupakan salah satu tindakan yang harus dilakukan, hal ini bertujuan agar segala tindakan yang nantinya diambil memiliki dasar hukum yang tepat.

\section{Judul Pemberitaan Kempat : "Mahasiswa Sarankan Walikota Tasikmalaya Mundur"}

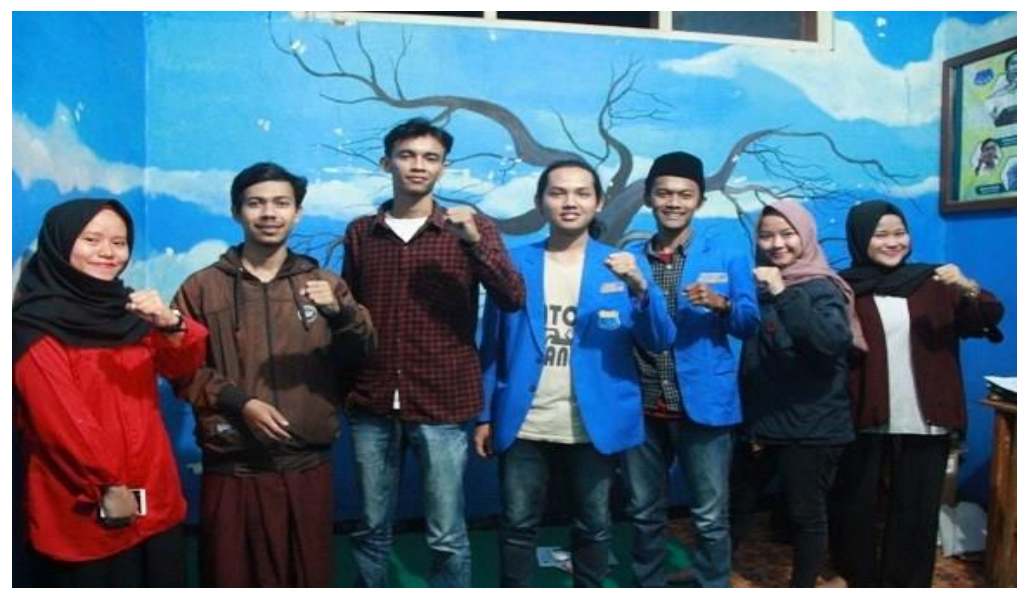

Sumber : radartasikmalaya.com, 2019

\section{Gambar 4. Sejumlah Mahasiswa Melakukan Forum terkait Status Walikota Tasikmalaya Dalam Kasus Suap}

Define Problems: Munculnya dorongan mahasiswa yang menginginkan Walikota Tasikmalaya untuk mundur dari jabatannya. Mahasiswa menuntut sikap DPRD ini dengan melakukan aksi teatrikal di depan Gedung DPRD Kota Tasikmalaya. Pengamat Politik dan 
Sosial, Bapak Asep M. Tamam menilai bahwa tindakan tersebut merupakan bentuk ketidakpuasan kinerja DPRD dalam menyikapi kasus ini, mereka menuntut untuk bertindak lebih tegas mengenai status Walikota Tasikmalaya yang sampai saat ini masih bertahan.

Diagnose Cause: Timbulnya citra kurang baik bagi roda pemerintah jika Walikota dengan status tersangka masih menjabat. Wartawan radartasikmalaya.com melihat penyebab masalah ini berawal dari tidak tegasnya tindakan yang diambil DPRD, sehingga mahasiswa menganggap jika DPRD sedang bermain "aman” dalam menyikapi kasus ini, tidak adanya informasi serta kejelasan proses penyelesaian kasus ini juga menjadi penyebab masalah dalam pemberitaan

Selain itu saat aksi ini dilakukan, sejumlah masa TI merasa tidak puas dengan jawaban sejumlah anggota fraksi yang hadir di DPRD. Dalam hal ini wartawan menonjolkan bagaimana suara-suara mahasiswa untuk DPRD, sejumlah permasalahan yang disuarakan oleh mahasiswa ini ditonjolkan dalam pemberitaan ini berbagai aspirasi-aspirahi ditampilkan dalam pemberitaan ini. Sehingga wartawan berusaha untuk menjadi wadah bagi mahasiswa yang kesal akan tindakan DPRD yang dinilai main aman.

Make Moral Judgement: Dalam pemberitaan ini berbagai suara mahasiswa menuntut DPRD yang bersikap aman ditonjolkan, keinginan sejumlah mahasiswa yang menginginkan agar Walikota Tasikmalaya mundur menjadi hal yang ditampilkan dalam membuat keputusan moral ini, hal ini juga sama dengan apa yang disampaikan oleh Tina Agustina selaku pimpinan redaksi radartasikmalaya.com

"Wajarlah jika mereka ingin Walikota Mundur, apalagi sekarang kan statusnya tersangka, kecemasan mereka ingin walikota mundur ini karena dapat berdampak pada citra pemerintah serta terganggunya roda pemerintahan"

Treatment Recommendation: Tak tinggal diam dengan aksi yang dilakukan oleh sejumlah massa di depan Gedung DPRD Kota Tasikmalaya, Ketua DPRD Kota Tasikmalaya, H Agus Wahyudin, S.H.,M.H ikut memberikan jawaban terkait pernyataan sejumlah massa yang ada di depan Gedung DPRD Kota Tasikmalaya.

Dengan adanya jawaban yang mengatakan jika pelayanan publik maupun roda pemerintah tidak terganggu akan adanya kasus ini. Selain itu wartawan pun menekankan jika jawaban dari Ketua DPRD terkait narasi-narasi yang disampaikan massa akan diserahkan ke proses hukum adalah hal yang ingin ditonjolkan dalam pemberitaan ini.

Ditambah dengan penyelesaian yang menyatakan jika DPRD Kota Tasikmalaya 
meyakinkan mahasiswa bahwa dengan adanya kasus ini tidak ikut mempengaruhi roda pemerintahan. Bahkan sejak adanya kasus ini DPRD telah melakukan perintah kepada komisi I agar pemerintahan tetap berjalan dengan baik seperti biasanya, menjadi fokus pada pemberitaan ini.

\section{Framing Pemberitaan Kasus Suap Anggaran DID dan DAK Walikota Tasikmalaya edisi April-Juli 2019 terkait Citra Pemerintah Kota Tasikmalaya}

Dewasa ini sering juga disebut sebagai era informasi, yang mana kehidupan kita dipengaruhi oleh berbagai informasi-informasi yang diperoleh. Informasi-informasi inilah yang menjadi landasan serta pertimbangan masyarakat dalam mengambil keputusan atau menilai informasi tersebut sebagai apa. Sedikit ataupun banyak informasi yang diperoleh oleh akan mempengaruhi perilaku dan juga tindakan masyarakat. Semakin masyarakat mendapatkan informasi yang tepat dan akurat, maka semakin tepat pula pilihan maupun penilaian yang diambil atas suatu persoalan tertentu.

Hal ini kita temukan dalam pemberitaan, pemberitaan atau berita yang dalam Kamus Besar Bahasa Indonesia memiliki arti sebagai "laporan tercepat mengenai kejadian atau peristiwa hangat". Sedangkan menurut Nimmo (1989 : 247) mengartikan berita sebagai proses menegosiasikan laporan yang bermakna tentang kejadian, yang mencakup simbolisasi (1) kejadian sebagai peristiwa; (2) peristiwa sebagai sesuatu yang bernilai; dan (3) peristiwa bernilai berita sebagai kisah berita.

Dalam kehidupan sehari-hari baik disadari atau tidak manusia melakukan berbagai aktivitasnya, binatang bergerak, tumbuhan berkembang, yang sangat sedikit menarik minat karena serba rutinitas. Namun sesekali "terjadi sesuatu" yang memecahkan kehidupan rutin yang normal, sesuatu yang tidak biasa bahkan mungkin luas biasa, orang meninggal, kecelakaan, bencana, perubahan politik, ekonomi dan sebagainya ; sesuatu yang tidak lagi rutin, situasi menjadi masalah. Orang-orang menuntut mendapatkan informasi yang cukup mengenai peristiwa itu, sehingga mereka dapat menyesuaikan diri dengan kejadian non rutin yang telah mendapat tambahan kepentingan. Peristiwa itu menjadi bernilai jika orang menganggap informasi mengenai peristiwa itu penting.

Lebih sederhananya, berita dapat disimpulkan menjadi 3 hal, yakni berita berbasis fakta peristiwa, peristiwa berita haruslah peristiwa yang memiliki nilai berita dan laporan peristiwa itu disampaikan kepada khalayak luas. Berita ditulis berdasarkan pada fakta-fakta 
suatu peristiwa, bukan berasal dari pikiran, opini atau pendapat pembuat berita. Wartawan hanya berfungsi untuk melaporkan fakta-fakta dengan berupaya menghindari munculnya opini pribadi dalam pemberitaannya agar kebenaran fakta tidak menjadi bias.

Sebagai seorang wartawan yang dituntut untuk menghasilkan berita kepada pembacanya, terlebih jika berita tersebut merupakan berita politik yang memiliki nilai berita yang tinggi, sehingga peristiwa politik hampir selalu menjadi perhatian media massa maupun masyarakat umum. Dalam hal ini wartawan sebagai penulis berita seringkali kesulitan untuk dapat menjaga obyektifitas pemberitaannya.

Hal ini juga tentu tidak terlepas dari media online seperti radartasikmlaya.com yang menerbitkan pemberitaan terkait kasus suap anggaran DID dan DAK yang dilakukan oleh Walikota Tasikmalaya untuk pertama kalinya. Disampaikan oleh Tina Agustina selaku pemimpin redaksi radartasikmalaya.com

“Waktu pemberitaan pertama terkait penggeledahan yang dilakukan KPK, radar merupakan media pertama yang memuat pemberitaan tersebut. Pengunjung portal kita langsung melonjak naik akibat adanya pemberitaan itu”

Sebagai salah satu media yang cukup berpengaruh di Kota Tasikmalaya, tentunya dalam memberitakan sebuah berita, media massa seperti radartasikmalaya.com tidak berdiri bebas dari kepentingan. Media melakukan seleksi isu atas apa yang ingin ditampilkan maupun dihilangkan. Oleh sebab itu bagian bingkai (frame) menjadi bagian yang penting dalam penulisan suatu berita. Pendekatan framing dipakai untuk mengetahui bagaimana realitas suatu peristiwa dibingkai oleh media. Setiap media memiliki cirinya tersendiri dalam memberitakan suatu peristiwa, dalam menyajikan berita yang akan disampaikan kepada khalayak tentunya harus mematuhi kebijakan-kebijakan yang telah ditetapkan oleh keredaksian yang tentunya dapat membatasi kebebasan wartawan dalam menuliskan dan mnyampaikan berita.

Disini radartasikmalaya.com telah berpartisispasi dalam pembuatan berita yang berkaitan dengan kasus suap anggaran DID dan DAK yang dilakukan oleh Walikota Tasikmalaya, diantaranya adalah pemberitaan dengan judul : Belasan Anggota KPK Geledah Kantor Walikota Tasikmalaya, Kapolresta Lakukan Pengamanan; Jadi Tersangka, Budi Tetap Jalankan Tugas; Walikota Tasik Minta Maaf; Mahasiswa Sarankan Walikota Tasikmalaya Mundur; dan Dewan Dinilai Main Aman.

Dalam menguji framing yang dilakukan oleh media onlineradartasikmalaya.com atas pemberitaan kasus Walikota Tasikmalaya terkait citra pemerintah Kota Tasikmalaya, 
terdapat dua aspek utama didalamnya diantaranya adalah seleksi isu serta penonjolan aspek tertentu dari suatu isu.

Jika itu berkaitan dengan seleksi isu, maka hal ini berkaitan dengan pemilihan fakta yang ada. Bagian mana yang akan diliput wartawan dai suatu isu maupun peristiwa yang sedang terjadi. Aspek pemilihan fakta ini tidak terlepas dari bagaimana fakta itu dipahami oleh media itu sendiri. Dalam melihat suatu peristiwa, wartawan maupun pembuat berita, mau tidak mau memakai kerangka konsep dan abstraksi dalam menggambarkan suatu realitas.

Dari berbagai seleksi isu yang ditonjolkan oleh media onlineradartasikmalya.com dalam pemberitaan kasus suap anggaran DID dan DAK yang dilakukan oleh Walikota Tasikmalaya, wartawan menseleksi isu hasil dari fakta yang mereka lihat dilapangan. Hal ini disampaikan oleh Firgi selaku wartawan radartasikmalaya.com:

"Apa yang kami tulis dalam pemberitaan tersebut adalah hasil apa yang kami lihat secara langsung dari lapangan"

Sebagai contoh seleksi isu yang dilakukan oleh wartawan radartasikmalaya.com terdapat pada pemberitaan dengan judul "Belasan Anggota KPK Geledah Kantor Walikota Tasikmalaya, Kapolresta Lakukan Pengamanan" dalam pemberitaan tersebut seleksi isu yang dimunculkan oleh wartawan berkaitan adanya penggeledahan yang dilakukan oleh KPK di Kantor Walikota Tasikmalaya.com. Seleksi isu yang dimunculkan hanya menjelaskan adanya penggeledahan di Kantor Walikota Tasikmalaya, namun nyatanya menurut Alan Suherlan selaku Jabatan Fungsional Umum (JFU) Penyusun Berita dan Pendapat Umum Kota Tasikmalaya, penggeledahan tidak hanya dilakukan di Kantor Walikota saja, tetapi dilakukan juga di ruangan Kepala Rumah Sakit Umum (RSU) Kota Tasikmalaya.

"Pers ataupun media menulis (berita) dari apa yang mereka lihat, tetapi tidak didukung dengan fakta yang ada. Yang mereka lihat dari penggeledahan tersebut adalah ketika KPK mengambil sejumlah barang bukti dari Kantor Walikota Tasikmalaya kedalam mobil dinas, faktanya KPK juga melakukan penggeledahan di Kantor dinas PUPR dan juga RSU”

Seleksi isu yang ditampilkan oleh radartasikmalaya.com dalam pemberitaan ini hanya menampilkan sisi penggeledahan yang dilakukan KPK di Kantor Walikota saja, hal ini dikarenakan tidak adanya penggalian fakta yang mendalam dikarenakan sebagai salah satu media, terlebih lagi media online, mereka dituntut untuk cepat dalam menyampaikan pemberitaan.

Fakta lainnya yang disampaikan oleh Alan Suherlan yakni, dalam pemberitaannya radartasikmalaya.com tidak melampirkan terkait penggeledahan yang dilakukan oleh KPK 
di RSU Kota Tasikmalaya, hal ini dikarenakan wartawan yang meliput penggeledahan di Kantor Walikota Tasikmalaya tidak turut melakukan pemburuan berita hingga ke RSU Kota Tasikmalaya.

Dalam proses pemilihan fakta ini dapat menimbulkan hasil ataupun akibat yang berbeda jauh. Hal dikarenakan ketika sebuah fakta didefinisikan maka disana akan ada proses pemilihan, yang dalam arti tertentu sebagai bentuk penonjolan, sehingga mengakibatkan penghilangan atas bagian tertentu dari suatu realitas. Proses pemilihan fakta ini, tidak hanya dipahami sebagai bagian dari tugas pembuat berita saja, akan tetapi terdapat isu politik pemberitaan didalamnya. Yakni, bagaimana dengan cara tertentu media secara tidak langsung mendefinisikan suatu realitas.

Pertama, dengan dilakukanya pemilihan fakta tertentu dan membuang fakta yang lain, realitas yang ditampilkan merupakan hasil "bentukan" tertentu untuk ditampilkan kepada khalayak. Pemberitaan terkait kasus suap anggaran DID dan DAK ini lebih menonjolkan tindakan-tindakan maupun kekhawatiran-kekhawatiran sejumlah khalayak kepada pemerintah Kota Tasikmalaya yang menilai tidak bertindak dalam menyikapi kasus yang menyeret Walikota Tasikmalaya, sehingga realitas yang timbul di masyarakat berkaitan dengan citra pemerintah yang dianggap buruk dalam menyikapi kasus ini. Kedua, mahasiswa selaku bagian dari masyarakat yang menyerahkan proses legitimasi kepada pemerintah, dengan menonjolkan berbagai tindakan maupun suara kekhawatiran mahasiswa terhadap pemerintah, secara tidak langsung media ikut menyorot pemerintah sebagai pihak yang disalahkan dan masyarakat sebagai korban.

Dengan pemilihan fakta berkaitan berbagai bentuk kekecewaan masyarakat terhadap tindakan pemerintah dalam menyikapi kasus suap anggaran DID dan DAK yang dilakukan oleh Walikota Tasikmalaya, dalam hal ini pemerintah yang disalahkan dan harus bersiap dipandang memiliki citra yang buruk di mata masyarakatnya.

Tidak hanya terkait seleksi isu yang menjadi penekanan dalam analisis framing model Robert N. Entman ini namun ada aspek terakhir didalamnya yakni aspek penonjolan aspek tertentu dari suatu isu. Penonjolan aspek tertentu dari suatu isu ini berkaitan dengan penulisan berita atas suatu realitas untuk dibaca oleh khalayak. Hal ini bisa dalam bentuk pemilihan gambar berita, judul maupun isi dari berita itu sendiri.

"Dalam menuliskan berita, radartasikmalaya.com tentunya selalu mempertimbangkan pemilihan gambar, judul hingga isi berita yang akan di terbitkan, hal ini tentunya penting guna menarik pembaca berita tersebut." 
Salah satu contoh penonjolan aspek tertentu dalam suatu isu, ada dalam pemberitaan dengan judul "Dewan Dinilai Main Aman" didalam pemberitaan tersebut pemilihan gambar berupa aktivis yang berpakaian mumi dengan latar belakang spanduk bertuliskan kekecewaan massa terhadap KPK. Faktanya menurut Alan Suherlan selaku Jabatan Fungsional Umum (JFU) Penyusun Berita dan Pendapat Umum Kota Tasikmalaya, dalam aksi teatrikal tersebut massa yang melakukan aksi di depan Gedung DPRD hanya berjumlah lebih kurang 10 orang, sisanya mahasiswa tersebut melakukanpublichearing di dalam kantor DPRD.

"Pemilihan gambar yang ditampilkan hanya sekedar bentuk aksi massa yang sedang menggunakan kostum dengan latar belakang spanduk, nyatanya saat itu juga sedang dilaksanakan kegiatan publichearing yang dilakukan oleh TI dalam kantor DPRD”

Tentunya dengan adanya aksi tersebut berdampak terhadap citra pemerintah Kota Tasikmalaya sendiri yang menganggap aksi ini merupakan akibat dari ketidaksigapan pemerintah dalam menangani kasus Walikota Tasikmalaya.

Citra sendiri memiliki pengertian yang abstrak atau intangible, tetapi wujudnya bisa dirasakan dari hasil penilaian, penerimaan, kesadaran, dan pengertian, baik semacam tanda respek dan rasa hormat, dari publik sekelilingnya atau masyarakat luas terhadap perusahaan atau institusi sebagai sebuah badan usaha ataupun terhadap personelnya (dipercaya, professional, dan dapat diandalkan dalam pemberian pelayanan yang baik).(dalam Rosady Ruslan 1999:50).

Menurut Pengamat Politik dan Sosial, Asep M. Tamam, dampak dari pemberitaan ini tidak terlalu berpengaruh terhadap citra Pemerintah Kota Tasikmalaya, hal ini terbukti dari tetap berjalannya pembangunan di Kota Tasikmalaya, seperti apa yang sebelumnya telah disampaikan oleh Walikota Tasikmalaya, ditengah masalah yang menjeratnya, ia akan terus membangun Kota Tasikmalaya untuk menjadi lebih baik lagi, diantaranya hasil pembangunan yang telah dicapai yakni : 1) Tidak kurang 600 kilometer jalan telah di hotmix 2) Dibukaya Bandara Wiriadinata, 3) Pembangunan Jalan Mangkubumi-Indihiang, 4) Menegrikan Universitas Siliwangi dan 5) Melanjutkan pembangunan RSU 5 lantai bagi warga kurang mampu, hingga merencanakan pembangunan Islamic Center di Kota Tasikmalaya.

Selain itu sebagai humas Pemerintah Kota Tasikmalaya, Alan Suherlan mengatakan bahwa pihaknya dan staff humas lainnya tidak berusaha untuk meng-counter pemberitaan yang ada di media massa. Justru pihaknya terus memberikan informasi seputar pembangunan Kota Tasikmalaya yang saat ini tengah berlangsung. 
"Kita tidak berusaha untuk menahan atau meng-counter pemberitaan yang tersebar di masyarakat lewat media massa. Kita disini tetap melaksanakan fungsi kami (Diskominfo) untuk menginformasikan kegiatan yang dilakukan otonomi daerah (pemerintah kota)"

Ini merupakan salah satu strategi yang dilakukan humas pemerintah dalam pembentukan citra sekaligus meredam berbagai opini yang tersebar di masyarakat. Berdasarkan wawancara dengan Asep M. Tamam, 21 Februari 2020, tampaknya dengan adanya berbagai pemberitaan yang muncul, salah satunya yang ada pada media online radartasikmalaya.com tidak memberikan pengaruh ketidakpercayaan dari masyarakat terhadap pemerintah, terbukti dengan berbagai pemberitaan berkaitan dengan pembangunan Kota Tasikmalaya yang terus dilakukan. Terlebih pemberitaan yang muncul tidak memberikan dampak terhadap citra negatif Pemerintah Kota Tasikmalaya.

Diskominfo selaku humas Pemerintah Kota Tasikmalaya mengaku, tak ada dampak negatif terhadap citra pemerintah dengan adanya pemberitaan-pemberitaan tersebut, bahkan masyarakat yang mengetahui adanya pemberitaan tersebut hanya memberikan komentar agar kasus ini dapat segera terselesaikan.

"Hingga sampai saat ini dampak dari kasus ataupun pemberitaan itu tidak membuat citra pemerintah jadi buruk dimata masyarakat, bahkan komentar-komentar yang muncul hanya sekedar keinginan mereka agar kasus ini dapat segera terselesaikan"

Faktor lain yang disampaikan oleh Bapak Asep Tamam terkait citra pemerintah dengan adanya kasus ini, yakni masyarakat lebih melihat pada hasil atau pencapaian yang dilakukan oleh Walikota Tasikmalaya dan pemerintah terhadap Kota Tasikmalaya.

"Kalau saya lihat maksud beliau melakukan gratifikasi tersebut sebagai bentuk cinta beliau terhadap masyarakat Kota Tasikmalaya, walaupun memang dengan cara yang salah, tapi itu adalah bukti ia berusaha untuk memajukan Kota Tasikmalaya"

Selain itu, menurut Asep Tamam dengan munculnya berita ini tidak memberikan dampak buruk terhadap citra pemerintah dimata masyarakat, dimana hal ini pemberitaan yang dilakukan oleh radartasikmalaya.com terkait kasus suap Walikota Tasikmalaya masih dalam batas aman dan tidak keluar dari konteks fakta yang ada. Ia juga mengatakan bahwa isi dari pemberitaan tersebut masih berimbang dalam memberitakan.

Terbukti dengan masih menjabatnya Walikota Tasikmalaya tidak menimbulkan berbagai permasalahan yang turut menyeret pemerintah Kota Tasikmalaya, hal ini dianggap karena masyarakat melihat jika kasus ini mulai meredam dan penyelesaian dari kasus ini pun masih belum menemukan titik terang. Sehingga masyarakat melihat bahwa kasus tersebut 
hanyalah isu yang muncul tanpa ada bukti dan penyelesaian yang benar hingga saat ini.

Disini dapat dilihat jika peran media atau dalam kasus ini adalah media online radartasikmalaya.com berperan untuk menyampaikan berita fakta ataupun sebagai penyebar informasi dari berbagai pihak yang memiliki kepentingan. Dalam hal inilah peran media tersebut harus berimbang dan jelas, disatu sisi media tentunya berperan sebagai jembatan masyarakat dalam mendapatkan informasi yang benar, sebaliknya disisi lain media juga berperan untuk menyebarkan suatu informasi tertentu untuk kepentingan pihak-pihak yang berkepentingan kepada masyarakat.

Public Relations atau Humas dalam sebuah organisasi maupun perusahaan harus selalu menjalin hubungan baik dengan pihak media. Hal ini sangatlah penting, karena media mendapatkan sumber berita yang berkualitas dengan penjelasan yang detail tanpa harus menganalisis berita, kemudian disisi lain pihak perusahaan mendapatkan kesempatan untuk mempublikasikan diri di media yang bersangkutan.

\section{SIMPULAN}

Simpulan dari penelitian ini secara umum, media online radartasikmalaya.com telah memaparkan berbagai fakta-fakta hasil penemuannya di lapangan berkaitan dengan kasus suap Walikota Tasikmalaya. Keputusan radartasikmalaya.com yang lebih menonjolkan suara maupun tindakan sejumlah massa terhadap keputusan pemerintah dalam menyikapi kasus ini, serta melihat jika pemerintah menjadi pihak yang bertanggungjawab atas kelanjutan kasus tersebut. Hal ini dikarenakan tugas pemerintah sebagai pelayan publik yang harus bias mengedepankan kepentingan masyarakatnya. Meskipun dengan adanya penonjolan aspek ini, citra pemerintah dirasa tidak terpengaruh dengan merebaknya pemberitaan tersebut. Hal ini dikarenakan masyarakat Kota Tasikmalaya yang lebih menilai terhadap pembangunan Kota itu sendiri, terlebih fakta jika sampai saat ini Walikota Tasikmalaya masih menjabat serta tetap menjalankan tugas menjadi bukti jika kasus yang beredar dianggap sebagai sebuah isu belaka. Dan juga keterbukaan pemerintah dengan media yang tidak berusaha untuk meng-counter pemberitaan yang beredar menjadi alas an masyarakat menilai bahwa berita tersebut hanyalah isu yang tengah menimpa pemimpin Kota Tasikmalaya. Sehingga citra pemerintah dalam hal ini tidak terpengaruh atau buruk dimata masyarakat Kota Tasikmalaya. 


\section{DAFTAR PUSTAKA}

Ardianto, (2011). HandbookofPublicRelations. Bandung.SimbiosaRekatama Media.

Eriyanto. (2002). AnalisisFraming (Konstruksi,Ideologi, dan Politik Media). Yogyakarta. YLKiS

F. Rachmadi (993). PublicRelationsDalamTeori dan Praktek. Jakarta. PT GramediaPustakaUtama

Kusumaningrat. (2012). Jurnalistik (Teori dan Praktik). Bandung. RemajaRosdakarya

Ruslan. (1997). Praktik dan SolusiPublicRelationsdalamSituasiKrisis dan PemulihanCitra. Jakarta. Ghalia Indonesia

Sugiyono. (2009). MemahamiPenelitianKualitatif. Bandung. Alfabeta.

\section{Sumber internet :}

Firgie.(2019, April 24). Radartasikmalaya.com. Diakses dari https://www.radartasikmalaya.com/belasan-anggota-kpk-geledah-kantor-wali-kotatasikmalaya-kapolresta-lakukan-pengamanan/

Firgie, (2019, April 26). Radartasikmalaya.com. Diakses dari https://www.radartasikmalaya.com/jadi-tersangka-budi-tetap-jalankan-tugas/

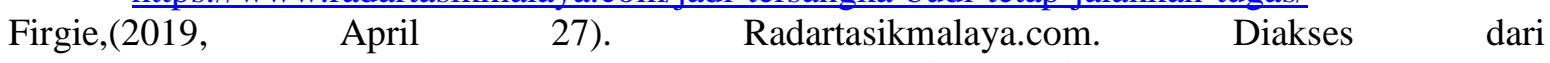
https://www.radartasikmalaya.com/wali-kota-tasik-minta-maaf/

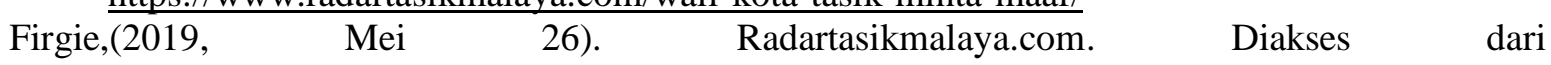
https://www.radartasikmalaya.com/mahasiswa-sarankan-wali-kota-tasikmalaya-mundur/ 